\title{
AKUNTANSI ZAKAT, INFAK DAN SEDEKAH (PSAK 109): Upaya Peningkatan Transparansi dan Akuntabilitas Organisasi Pengelola Zakat (OPZ)
}

\author{
Taufikur Rahman \\ Institut Agama Islam Negeri (IAIN) Salatiga \\ takur067782@yahoo.co.id
}

\begin{abstract}
This article discuss one of the tools that used Zakat Management Organization (OPZ) to created good zakat governance system. One of the characteristics of good zakat governance is transparency and accountability in the management of zakat included the management on infaq/sedekah. As a manager's of funds people that depend on donates from the people, transparency and accountability is a major concern for Zakat Management Organization (OPZ). More transparent and accountable in the management of zakat, infaq and sedekah will make public trust higher to formal Zakat Management Organization (OPZ). The high trust to the OPZ would be foster awareness, compliance and motivate people (Muzakki) to voluntarily distribute zakat, infaq and sedekah through official or formal Zakat Management Organization (BAZNAS and LAZ). Good accounting and financial reporting system can help OPZ to created transparency and accountability. To produce the good, true, the creation of uniformity and comparability in the accounting and financial reporting, and make OPZ prepared to be audited by public accountant, the activity of accounting and preparation of OPZ financial statements must refers to a guideline or standard that is standard accounting for zakat, infaq and sedekah (ZIS). ZIS accounting standard refer to Indonesia today is statement of financial accounting standards 109 (PSAK 109) about zakat, infaq and sedekah accounting that issued by the Indonesian Institute of Accountant (IAI). PSAK no. 109 is used as a guidline for OPZ in the recognation, measurement, presentation and disclosure of transactions zakat, infak and sedekah.
\end{abstract}

Keywords: Zakat, infaq and sedekah Accounting, Transparency, Accountability 


\begin{abstract}
Abstrak
Artikel ini membahas salah satu instrumen (tool) yang digunakan Organisasi Pengelola Zakat (OPZ) dalam menciptakan sistem tata kelola zakat yang baik (good zakat governance). Karakteristik good zakat governance di antaranya adalah transparansi dan akuntabilitas dalam pengeloaan zakat yang termasuk di dalamnya pengelolaan infak/sedekah. Sebagai pengelola dana umat yang mengandalkan donatur dari umat, transparansi dan akuntabilitas dalam pengelolaan Zakat dan Infak/Sedekah (ZIS) menjadi perhatian utama OPZ. Semakin transparan dan akuntabel OPZ dalam pengelolaan ZIS, maka akan semakin tinggi kepercayaan masyarakat terhadap OPZ. Tingginya kepercayaan terhadap OPZ akan menumbuhkan kesadaran, kepatuhan dan memotivasi masyarakat (Muzakki) untuk secara sukarela menyalurkan zakat dan infak/sedekahnya melalui OPZ resmi/formal (BAZNAS dan LAZ) yang ada. Sistem pembukuan dan pelaporan keuangan yang benar dapat membantu mewujudkan transparansi dan akuntabilitas suatu OPZ. Untuk menghasilkan sistem pembukuan dan pelaporan keuangan yang baik, benar, terciptanya keseragaman (uniformity) dan keterbandingan (comparability) dalam pelaporan keuangan serta supaya OPZ siap diaudit oleh akuntan publik, maka aktivitas pembukuan dan penyusunan laporan keuangan OPZ mengacu pada suatu pedoman atau standar yaitu standar akuntansi zakat dan infak/sedekah. Standar akuntansi ZIS yang berlaku di Indonesia sekarang ini adalah Pernyataan Standar Akuntansi Keuangan (PSAK) nomor 109 mengenai akuntansi zakat dan infak/sedekah yang dikeluarkan oleh Ikatan Akuntan Indonesia (IAI). PSAK no. 109 digunakan sebagai pedoman bagi OPZ dalam pengakuan, pengukuran, penyajian dan pengungkapan transaksitransaksi zakat dan infak/sedekah.
\end{abstract}

Kata Kunci:Akuntansi Zakat dan Infak/sedekah, Transaparansi, Akuntabilitas

\title{
Pendahuluan
}

Zakat merupakan salah satu ibadah pokok dalam Islam yang dapat menjadi pilar utama dan tool untuk menegakkan keadilan dalam kehidupan sosial serta dapat meningkatkan kesejahteraan umat. Zakat menurut istilah fiqh Islam adalah sejumlah harta tertentu yang wajib dikeluarkan dari kekayaan orang-orang kaya (the have) untuk diserahkan kepada orang-orang yang berhak menerimanya menurut aturan-aturan atau syariat Allah SWT 
(Anshori, 2006: 12). Menurut Undang-Undang No. 23 Tahun 2011, zakat adalah harta yang wajib dikeluarkan oleh seorang Muslim atau badan usaha untuk diberikan kepada yang berhak menerimanya sesuai dengan syariat Islam. Dalam UU tersebut disebutkan bahwa tujuan dari zakat adalah untuk mewujudkan kesejahteraan masyarakat, meningkatkan keadilan sosial dan penanggulangan kemiskinan sehingga diharapkan di masyarakat tidak terjadi gap atau kesenjangan yang tinggi antara si kaya dengan si miskin. Menurut PSAK No. 109, tujuan zakat yang mulia tersebut akan dapat tercapai apabila dalam pengelolaan zakat dilakukan secara baik dan professional (good zakat governance), artinya bahwa zakat seharusnya dikelola secara melembaga sesuai dengan syariat Islam, amanah, kemanfaatan, keadilan, kepastian hukum, terintegrasi, dan akuntabilitas.

Pengelolaan Zakat menurut Undang-Undang No. 23 Tahun 2011 adalah suatu kegiatan perencanaan, pelaksanaan dan pengorganisasian dalam pengumpulan, pendistribusian dan pendayagunaan zakat. Di Indonesia, lembaga yang berwenang melakukan kegiatan itu adalah lembaga pengelola zakat yang formal dan berbadan hukum yaitu Badan Amil Zakat Nasional (BAZNAS) yang dibentuk oleh pemerintah dan Lembaga Amil Zakat (LAZ) yang dibentuk oleh masyarakat dan dikukuhkan pemerintah. Dalam melaksanakan tugas dan fungsinya, BAZNAS dapat dibantu oleh Unit Pengumpul Zakat (UPZ). UPZ merupakan satuan organisasi yang dibentuk oleh BAZNAS untuk membantu mengumpulkan zakat.

Salah satu kegiatan utama dari beberapa kegiatan yang dilakukan oleh organisasi pengelola zakat adalah pengumpulan zakat. Aktivitas itu sangat tergantung kepada para donatur (Muzakki). Selama masih ada muzakki yang menyalurkan zakatnya pada OPZ maka fungsi OPZ akan berjalan secara baik, namun sebaliknya ketika tidak ada muzaki yang menyalurkan zakatnya pada OPZ maka OPZ tidak akan berfungsi sebagaimana mestinya. Oleh karena itu, salah satu usaha yang wajib dilakukan oleh OPZ adalah bagaimana menumbuhkan kesadaran, kepatuhan dan motivasi masyarakat Muslim yang mampu untuk menunaikan kewajiban zakatnya kepada OPZ terutama kepada organisasi formal yang berbadan hukum (BAZNAS dan LAZ). 
Potensi zakat yang dapat dihimpun di Indonesia sebetulnya sangat besar, karena secara demografis mayoritas penduduk Indonesia adalah Muslim. Hal tersebut ditunjukkan dari hasil penelitian yang pernah dilakukan BAZNAS bekerjasama dengan Fakultas Ekonomi Manajemen (FEM) IPB dan Islamic Development Bank pada tahun 2011, bahwa potensi zakat secara nasional mencapai angka 3,40 persen dari total Produk Domestik Bruto (PDB) yakni potensi zakat nasional sebenarnya kurang lebih mencapai Rp. 217 Triliun pertahun (Majalah Zakat Edisi Mei 2013). Ironisnya realitas menunjukkan bahwa tidak semua potensi zakat yang besar tersebut dapat terealisasi sesuai harapan. Realisasi pengumpulan zakat di Indonesia saat ini masih jauh dari potensi zakat yang ada. Pada tahun 2011 berdasarkan data BAZNAS, penerimaan zakat di Indonesia baru sebesar Rp. 1,7 triliun, kemudian penerimaan zakat pada tahun 2012 baru sekitar 1\% dari potensi zakat di Indonesia yaitu Rp. 2,73 triliun Data tersebut menunjukkan bahwa masih terjadi gap antara potensi zakat dengan realisasi pengumpulan zakat yang ada saat ini.

Beberapa faktor penyebab rasio penghimpunan zakat di Indonesia terlihat sangat kecil, yang pertama adalah faktor kesadaran masyarakat yang kurang, kedua adalah pemahaman dan sosialisasi yang masih kurang, ketiga adalah faktor kepercayaan atau trust terhadap OPZ yang rendah, keempat adalah keterbukaan yang masih kurang, kelima adalah budaya masyarakat Indonesia yang sudah menjadi kebiasaan selama berabad-abad cenderung lebih suka membayar zakat secara langsung tidak melalui lembaga formal berbadan hukum (BAZNAS dan LAZ). Menurut survei yang pernah dilakukan Public Interest Research and Advocacy Centre (PIRAC) pada tahun 2007 menunjukkan bahwa salah satu faktor penyebab terjadinya penurunan penyaluran zakat oleh Muzakki kepada BAZNAS dan LAZ adalah menurunnya tingkat kepercayaan masyarakat kepada pengelola zakat, baik BAZNAS maupun LAZ (PIRAC: 2007). Begitu juga hasil survei nasional yang dilakukan oleh UIN Syarif Hidayatullah Jakarta juga menunjukkan hasil yang tidak jauh berbeda yaitu 97\% masyarakat menginginkan BAZNAS dan LAZ bekerja secara akuntabel dan transparan, $90 \%$ meminta adanya kemudahan akses untuk melakukan pengawasan terhadap dana yang dikelola, 90\% menunt ut pempublikasian laporan keuangan OPZ di media 
massa. Selanjutnya, 75\% masyarakat tidak ingin menyalurkan zakatnya ke lembaga zakat yang kurang diketahui akuntabilitasnya. Bahkan, 63\% masyarakat ingin mengetahui ke mana dana zakat diserahkan. Hasil survei di atas menunjukkan bahwa salah satu faktor penting yang menyebabkan rendahnya optimalisasi zakat di Indonesia adalah rendahnya kepercayaan (trust) masyarakat terhadap kualitas pengelolaan zakat yang dilakukan oleh OPZ. Hal ini menjadi pekerjaan rumah bagi OPZ untuk segera melakukan usaha yang maksimal untuk menumbuhkan kepercayaan masyarakat terhadap OPZ saat ini.

Rendahnya kepercayaan umat terhadap OPZ akan berimbas pada gagalnya optimalisasi potensi zakat saat ini. Oleh karena itu, salah satu alat yang dapat digunakan OPZ untuk menumbuhkan kepercayaan umat terhadap kualitas OPZ adalah dengan mengaplikasikan suatu sistem akuntansi yang baik dalam pengelolaan zakat. Sistem akuntansi yang baik diharapkan pengelolaan zakat oleh OPZ akan menjadi lebih efektif, efisien dan lebih transparan (jelas sumber dan penggunaan dana zakat) serta lebih akuntabel (dapat dipertanggungjawabkan). Sistem akuntansi adalah formulir-formulir, catatan-catatan, prosedur-prosedur dan alat-alat yang digunakan untuk mengolah data mengenai usaha suatu kegiatan ekonomis dengan tujuan untuk menghasilkan umpan balik dalam bentuk laporan-laporan yang diperlukan oleh manajemen untuk mengawasi usahanya dan pihak-pihak yang berkepentingan yang lain (Muzakki, pemerintah, mustahik, masyarakat/umat) untuk menilai hasil operasional (Howard F. Settler dalam Hariningsih, 2006: 3). Menurut Mulyadi (2001: 3) sistem akuntansi adalah organisasi formulir, catatan dan laporan yang dikoordinasi untuk menyediakan inforrmasi keuangan yang dibutuhkan oleh manajemen guna memudahkan pengelolaan perusahan.

Ikatan Akuntan Indonesia (IAI) sebagai organisasi profesi akuntan di Indonesia berupaya memberikan kontribusi dalam rangka mewujudkan sistem akuntansi yang baik dari suatu OPZ. Pada tahun 2010, IAI menerbitkan Pernyataan Standar Akuntansi Keuangan (PSAK) No. 109. PSAK ini bertujuan untuk mengatur tentang akuntansi zakat, infaq dan shadaqah yakni mengatur pengakuan, pengukuran, penyajian dan pengungkapan transaksi zakat dan infak/sedekah yang berlaku bagi 
Organisasi Pengelola Zakat yang berkewajiban menghimpun dan menyalurkan zakat dan infak/sedekah. PSAK tersebut diterbitkan sebagai pedoman standardisasi dalam pencatatan transaksi dan penyusunan laporan keuangan yang dibuat oleh Organisasi Pengelola Zakat. Dengan adanya standardisasi tersebut maka akan terjadi keseragaman (uniformity) dan keterbandingan (comparability) dalam pencatatan dan pelaporan keuangan yang dibuat oleh Organisasi Pengelola Zakat yang ada di Indonesia, hal ini juga dapat membantu memudahkan akuntan publik dalam melakukan audit atas laporan keuangan OPZ.

\section{Pengertian Zakat, Infaq, Sedekah (ZIS) dan Akuntansi ZIS}

Pengertian zakat secara terminologi berarti kegiatan memberikan harta tertentu yang diwajibkan Allah SWT dalam jumlah dan perhitungan tertentu untuk diserahkan kepada orang-orang yang berhak. Zakat menurut istilah Fiqh Islam adalah sejumlah harta tertentu yang wajib dikeluarkan dari kekayaan orang-orang kaya (the have) untuk diserahkan kepada orang-orang yang berhak menerimanya menurut aturan-aturan atau syariat Allah SWT (Anshori, 2006: 12). Menurut Pernyataan Standar Akuntansi Keuangan (PSAK) no. 109, zakat adalah harta yang wajib dikeluarkan oleh muzakki sesuai dengan ketentuan syariah untuk diberikan kepada yang berhak menerimanya (mustahik). Zakat adalah harta yang wajib dikeluarkan oleh seorang muslim atau badan usaha untuk diberikan kepada yang berhak menerimanya sesuai dengan syariat Islam (UU No. 23 Tahun 2011).

Infak menurut terminologi artinya mengeluarkan harta karena taat, patuh dan cinta kepada Allah SWT dan sebagai wujud rasa syukur atas nikmat atau rezeki yang telah diberikan Allah SWT kepada dirinya. Sedangkan pengertian shadaqah adalah segala pemberian/aktivitas yang bertujuan untuk mengharap pahala dari Allah SWT. Shadaqah memiliki dimensi yang sangat luas, tidak hanya berdimensi memberikan sesuatu dalam bentuk harta saja, tetapi dapat berupa berbuat kebajikan, baik untuk diri sendiri maupun untuk orang lain. Menurut UU 23 Tahun 2011, Infak adalah harta yang dikeluarkan oleh seseorang atau badan usaha diluar zakat untuk kemaslahatan umum. Sedangkan sedekah adalah harta atau non harta yang dikeuarkan oleh seseorang atau badan usaha diluar zakat untuk kemaslahatan 
umum. Untuk kepentingan akuntansi, shadaqah dianggap sama dengan infak, baik yang ditentukan penggunannya maupun yang tidak. Sehingga menurut Pernyataan Standar Akuntansi Keuangan (PSAK) No. 109 Infak/sedekah adalah harta yang diberikan secara sukarela oleh pemiliknya, baik yang peruntukannya dibatasi (ditentukan) maupun tidak dibatasi. Sifat dari zakat adalah wajib bagi seseorang atau badan hukum (entitas) yang beragama Islam yang telah terakumulasi sampai memenuhi nisab dan haul. Sedangkan sifat dari infaq dan shadaqah adalah sunnah, jadi pengeluarannya lebih bersifat suka rela yang merupakan wujud ketakwaan dan kecintaan seorang hamba terhadap nikmat Allah SWT yang telah diberikan kepadanya.

Ditinjau dari sudut kegiatannya, akuntansi dapat didefinisikan sebagai proses pencatatan, penggolongan, peringkasan, pelaporan, dan penganalisisan data keuangan suatu organisasi (Jusup, 2005: 5). Menurut Mulyadi (1993: 2) akuntansi adalah "proses pengolahan data keuangan untuk menghasilkan informasi keuangan yang digunakan untuk memungkinkan pengambilan keputusan melakukan pertimbangan berdasarkan informasi dalam pengambilan keputusan". Jadi, akuntansi zakat dan infak/sedekah dapat diartikan sebagai suatu proses akuntansi atas transaksi-transaksi zakat dan infak/ sedekah berdasarkan prinsip-prinsip syariah Islam yang dapat menghasilkan informasi keuangan berupa laporan keuangan yang dapat digunakan untuk pengambilan keputusan pihak-pihak yang berkepentingan seperti muzakki dan calon muzakki, pemerintah, masyarakat/umat, mustahik dan pihak lain. Tujuan dari akuntansi ZIS menurut Pernyataan Standar Akuntansi Keuangan (PSAK) 109 adalah untuk mengatur pengakuan, pengukuran, penyajian dan pengungkapan transaksi zakat dan infak/sedekah. Akuntansi ZIS dapat diaplikasikan atau digunakan untuk membantu para amil yang menerima dan menyalurkan ZIS atau entitas yang kegiatan utamanya menerima dan menyalurkan ZIS.

\section{Tinjauan Tentang Organisasi Pengelola Zakat (OPZ) Dalam Undang-Undang No. 23 Tahun 2011}

Masalah pengelolaan zakat dan Organisasi Pengelola Zakat (OPZ) pada awalnya diatur dalam Undang-Undang No. 38 tahun 1999, namun karena Undang-Undang tersebut dinilai sudah tidak sesuai lagi dengan 
perkembangan dan kebutuhan hukum dalam masyarakat maka UU tersebut disempurnakan menjadi Undang-Undang no. 23 Tahun 2011 tentang Pengelolaan Zakat. Dalam UU tersebut, yang dimaksud pengelolaan zakat adalah kegiatan perencanaan, pelaksanaan, dan pengoordinasian dalam pengumpulan, pendistribusian, dan pendayagunaan zakat yang bertujuan untuk meningkatkan efektivitas dan efisiensi pelayanan dalam pengelolaan zakat dan meningkatkan manfaat zakat untuk mewujudkan kesejahteraan masyarakat dan penanggulangan kemiskinan. Sedangkan lembaga yang berwenang melakukan tugas pengelolaan zakat, infak dan sedekah disebut dengan Organisasi Pengelola Zakat.

UU no. 23 Tahun 2011 menyebutkan bahwa terdapat dua Organisasi Pengelola Zakat yang berwenang melakukan pengelolaan zakat di Indonesia yakni Badan Amil Zakat Nasional (BAZNAS) dan Lembaga Amil Zakat (LAZ). Badan Amil Zakat Nasional (BAZNAS) adalah Organisasi Pengelola Zakat yang dibentuk oleh pemerintah. BAZNAS tersebar hampir disetiap tingkatan daerah baik tingkat pusat, provinsi dan kabupaten/kota. BAZNAS berwenang melakukan tugas pengelolaan zakat secara nasional. BAZNAS merupakan lembaga pemerintah nonstruktural yang bersifat mandiri dan bertanggungjawab kepada Presiden melalui Menteri. Fungsi BAZNAS adalah menyelenggarakan perencanaan, pelaksanaan, pengendalian dalam pengumpulan, pendistribusian dan pendayagunaan zakat serta menyelenggarakan pelaporan dan pertanggungjawaban pelaksanaan pengelolaan zakat. BAZNAS melaporkan hasil pelaksanaan tugasnya secara tertulis kepada Presiden melalui Menteri dan kepada Dewan Perwakilan Rakyat Republik Indonesia.

LAZ adalah lembaga yang dibentuk masyarakat yang memiliki tugas membantu pengumpulan, pendistribusian dan pendayagunaan zakat. Pembentukan LAZ wajib mendapat izin Menteri atau pejabat yang ditunjuk oleh Menteri. LAZ wajib melaporkan pelaksanaan pengumpulan, pendistribusian, dan pendayagunaan zakat yang telah diaudit kepada BAZNAS secara berkala. Dalam melaksanakan tugas dan fungsinya, BAZNAS dapat dibantu Unit Pengumpul Zakat (UPZ). UPZ merupakan satuan organisasi yang dibentuk oleh BAZNAS untuk membantu mengumpulkan zakat. 
Berkaitan dengan pelaporan pelaksanaan pengelolaan zakat, infak/ sedekah dan dana sosial keagamaan lainnya, BAZNAS kabupaten/kota wajib menyampaikan pelaksanaan pengelolaan ZIS dan dana sosial keagamaan lainnya kepada BAZNAS provinsi dan pemerintah daerah secara berkala. Selanjutnya BAZNAS provinsi wajib menyampaikan laporan pelaksanaan ZIS dan dana sosial keagamaan lainnya kepada BAZNAS dan pemerintah daerah secara berkala. LAZ wajib menyampaikan laporan pelaksanaan pengelolaan ZIS dan dana sosial keagamaan lainnya kepada BAZNAS dan pemerintah daerah secara berkala. Selanjutnya BAZNAS wajib menyampaikan pelaksanaan pengelolaan ZIS dan dana sosial keagamaan lainnya kepada Menteri secara berkala. Laporan neraca tahunan BAZNAS diumumkan melalui media cetak atau media elektronik.

Untuk melakukan tugasnya, BAZNAS dibiayai dengan Anggaran Pendapatan dan Belanja Negara dan Hak Amil. Sedangkan BAZNAS provinsi dan BAZNAS kabupaten/kota dibiayai dengan Anggaran Pendapatan dan Belanja Daerah dan Hak Amil, serta juga dapat dibiayai dengan Anggaran Pendapatan dan Belanja Negara. Pembinaan dan pengawasan terhadap BAZNAS, BAZNAS provinsi, BAZNAS kabupaten/kota, dan LAZ dilaksanakan oleh Menteri. Gubernur dan Bupati/Walikota melaksanakan pembinaan dan pengawasan terhadap BAZNAS provinsi, BAZNAS kabupaten/kota, dan LAZ sesuai dengan kewenangannya. Pembinaan tersebut meiputi fasilitasi, sosialisasi dan edukasi. Masyarakat dapat berperan serta dalam pembinaan dan pengawasan terhadap BAZNAS dan LAZ. Pengawasan yang dimaksud pertama, berupa akses terhadap informasi tentang pengelolaan zakat yang dilakukan oleh BAZNAS dan LAZ. Kedua,penyampaian informasi apabila terjadi penyimpangan dalam pengelolaan zakat yang dilakukan oleh BAZNAS dan LAZ.

Diterbitkannya UU tentang pengelolaan zakat yang baru menimbulkan pro dan kontra di masyarakat, tidak semua isi dan pasal yang ada dalam UU tersebut dapat diterima oleh semua pihak dan masyarakat. UU zakat yang baru mendapatkan kritik keras dari banyak LAZ dan sebagian masyarakat yang selama ini menjadi amil zakat secara tradisional. Sebagaimana yang disampaikan oleh Juwaini (2011), kritik tersebut ditujukan kepada tiga masalah krusial yang ada didalamnya, yaitu: pertama, syarat 
izin pendirian LAZ adalah harus didirikan oleh organisasi kemasyarakatan Islam. Padahal kenyataannya saat ini banyak LAZ yang telah berdiri dan beroperasi namun tidak didirikan oleh ormas Islam. Kedua, tidak diatur dan dijelaskannya kedudukan dan posisi LAZ daerah, baik LAZ propinsi mupun LAZ kabupaten/kota. Ketiga, tidak diperkenankannya kelompok masyarakat atau organisasi untuk mengelola zakat, apabila kelompok masyarakat atau organisasi tersebut tidak memiliki izin sebagai LAZ. Apabila ketentuan tersebut dilanggar, maka konsekuensi berat yang dapat ditimpakan adalah mendapatkan ancaman pidana. Menanggapi adanya tiga persoalan tersebut, pemerintah melalui Sekjen Kementerian Agama dan Ketua Umum BAZNAS sebetulnya sudah memberikan penjelasan bahwa ketiga hal tersebut akan diakomodasi dan diserap dalam Peraturan Pemerintah (PP) dan PERMENAG, akan tetapi sebagian LAZ dan masyarakat masih tetap khawatir bahwa PP dan PERMENAG yang nanti dibuat justru akan memperkuat muatan tersurat yang ada pada UU zakat yang baru tersebut.

Hasil dari uji material oleh Mahkamah Konstitusi terhadap UU Pengelolaan Zakat tersebut dapat diringkas: 1) Dikuatkannya peran BAZNAS sebagai pemain utama pengelolaan zakat di Indonesia, 2) Masyarakat diperkenankan mengelola zakat selama mendapatkan izin/pengukuhan dari pemerintah (dalam bentuk LAZ), atau kalau di daerah yang belum terjamah operasi BAZNAS dan LAZ, maka pengelola zakat lainnya (seperti masjid, pesantren dan kyai) diharuskan memberitahukan kepada pejabat terkait, 3) Persyaratan pengukuhan LAZ tidak mensyaratkan badan hukumnya harus ormas atau perkumpulan, tapi dapat juga berbentuk yayasan, 4) Masyarakat lainnya dianjurkan untuk menjadi Unit Pengelola Zakat (UPZ), baik UPZ BAZNAS maupun UPZ LAZ, 5) Menegaskan BAZNAS sebagai "coordinator administratif" pengelola zakat di Indonesia, 6) Pelaksanaan sanksi pidana terhadap pengelola zakat dilakukan secara bertahap, 7) Semua pengelola zakat yang telah berijin/dikukuhkan sebagaimana poin (2) dan menjadi UPZ sebagaimana point (4) tidak akan mendapatkan sanksi pidana (Juwaini, 2013). 


\section{Peran sistem Informasi Akuntansi bagi Organisasi Pengelola Zakat (OPZ)}

Organisasi Pengelola Zakat merupakan salah satu bentuk organisasi nirlaba atau termasuk kategori non for profit organization, suatu bentuk organisasi yang tidak berorientasi pada laba (non bisnis) tapi lebih bersifat charity (sosial). Menurut Wilson dan Kattelus (2002) karakteristik organisasi nirlaba adalah pertama, sebagian besar sumberdaya organisasi (dana atau barang) tergantung pada penyedia sumberdaya (donatur) yang tidak mengharapkan timbal balik/return, atau ikhlas menyumbangkan sumberdayanya tanpa pamrih. Kedua, operasional organisasi adalah menyediakan barang atau jasa tetapi tidak bertujuan memperoleh keunt ungan. Ketiga, tidak ada ownership interest (kepentingan pemilik) seperti perusahaan bisnis. Menurut Pernyataan Standar Akuntansi Keuangan Nomor 45 organisasi nirlaba adalah orgnisasi yang memenuhi karakteristik sebagai berikut:

1. Sumber daya entitas berasal dari para penyumbang yang tidak mengharapkan pembayaran kembali atau manfaat ekonomi yang sebanding dengan jumlah sumber daya yang diberikan.

2. Menghasilkan barang dan/atau jasa tanpa bertujuan memupuk laba, dan kalau suatu entitas menghasilkan laba, maka jumlahnya tidak pernah dibagikan kepada para pendiri atau pemilik entitas tersebut.

3. Tidak ada kepemilikan seperti lazimnya pada orgnisasi bisnis, dalam arti bahwa kepemilikan dalam organisasi nirlaba tidak dapat dijual, dialihkan, atau ditebus kembali, atau kepemilikan tersebut tidak mencerminkan proporsi pembagian sumber daya entitas pada saat likuidasi atau pembubaran entitas

Melihat karakteristik organisasi tersebut, maka aktivitas operasional Organisasi Pengelola Zakat terutama dalam hal pengumpulan sumberdaya (zakat, infak, sedekah dan dana sosial keagamaan lainnya) sangat tergantung dari para donatur (Muzakki). Artinya, muzakki adalah pihak yang memiliki peran penting dalam kelancaran aktivitas operasional suatu OPZ. OPZ didirikan atas dasar niat demi kepentingan umum (umat), bukan untuk kepentingan sekelompok orang yang menjadi pengelolanya. Organisasi ini 
beroperasi dalam bidang penitipan amanat dalam bentuk harta dari para penyandang dana karena adanya ajaran syariah. Dana yang diperoleh tidak dapat digunakan secara sembarangan atau sekehendak pengelola, akan tetapi dibatasi oleh aturan syariah yang ada.

Menurut UU No 23 Tahun 2011 pasal 1 kegiatan pengelolaan terdiri dari perencanaan, pelaksanaan, dan pengkoordinasian dalam pengumpulan, pendistribusian, dan pendayagunaan zakat. Untuk menunjukkan bahwa zakat (termasuk Infak dan sedekah) benar-benar dikelola secara baik dan benar maka perlu adanya suatu sistem informasi yang dapat memberikan gambaran yang jelas dan transparan tentang aktivitas terkait dengan pengelolaan zakat. Sistem Informasi tersebut juga harus menyajikan informasi yang cukup, dapat dipercaya, dapat diandalkan, mudah dipahami dan relevan bagi para penggunanya, serta tetap dalam konteks syariah Islam. Salah satu sistem informasi yang dapat digunakan untuk mencapai tujuan tersebut adalah sistem informasi akuntansi.

Secara umum sistem informasi dapat dikelompokkan menjadi dua yaitu sistem informasi akuntansi keuangan dan sistem informasi akuntansi manajemen. Keluaran yang dihasilkan dari suatu sistem informasi akuntansi ini adalah informasi yang lebih bersifat kuantitatif sehingga lebih mampu unt uk mengurangi ketidakpastian. Sedangkan tujuan atau manfaat dari informasi tersebut adalah menyediakan informasi dari suatu organisasi kepada para pihak yang berkepentingan sebagai dasar dalam pengambilan suatu keputusan terutama keputusan yang bersifat ekonomi. Pihak-pihak yang berkepentingan tersebut dapat pihak internal maupun eksternal. Dalam kaitanya dengan OPZ maka pihak internal adalah manajemen OPZ, sedangkan pihak eksternal misalnya adalah muzaki, mustahik, pemerintah, masyarakat umum dan pihak lain. Dari sisi pihak internal yakni manajemen OPZ, informasi akuntansi digunakan untuk memenuhi keperluan dalam perencanaan, pengkoordinasian, pengarahan, pengevaluasian kinerja internal dan pengendalian aktivitas organisasi. Dari sisi pihak eksternal terutama para muzaki, mereka adalah pihak yang paling berkepentingan dengan hasil dari informasi akuntansi karena berkaitan dengan informasi pertanggungjawaban keuangan atau dana ZIS yang telah diamanatkan pada suatu OPZ, mereka (muzaki) ingin mengetahui apakah dana ZIS yang 
dipercayakan kepada OPZ dikelola secara baik dan benar, penyaluran dana ZIS sudah sesuai dengan peruntukkanya atau belum. Informasi-informasi tersebut tentu dapat diperoleh dari keluaran yang dihasilkan oleh informasi akuntansi keuangan yaitu laporan keuangan yang dibuat OPZ.

Hasil akhir dari suatu proses akuntansi adalah pembuatan laporan keuangan. Laporan keuangan tersebut dapat menunjukkan aktivitas/transaksi apa saja yang telah dilakukan OPZ selama suatu periode tertentu. Aktivitas yang dilaporkan dalam laporan keuangan tentunya adalah aktivitas-aktivitas yang lebih bersifat keuangan, meskipun juga ada yang bersifat non kuangan. Laporan keuangan juga dianggap sebagai bentuk dari pertanggungjawaban OPZ atas pengelolaan dana ZIS yang telah diamanatkan kepada mereka, apakah dana ZIS dikelola secara benar atau tidak (akuntabilitas). Karena OPZ termasuk organisasi sektor publik yang sumber dananya berasal dari publik, maka perlu adanya transparansi dalam pelaporan keuangannya. Unsur transparansi dapat terpenuhi apabila OPZ menyampaikan informasi yang benar-benar relevan, akurat dan tepat waktu serta mempublikasikan laporan keuangan yang telah dibuat melalui media massa, baik media cetak maupun elektronik. Sehingga, sebelum laporan keuangan tersebut dipublikasikan maka perlu dilakukan audit terlebih dahulu oleh akuntan publik untuk mengetahui apakah laporan keuangan tersebut benar-benar sesuai dengan standar yang berlaku.

Informasi akuntansi suatu organisasi baik yang berorientasi laba maupun tidak sebetulnya memiliki tujuan yang hampir sama, yakni membangun sebuah kepercayaan. Kepercayaan dari pihak-pihak yang berkepentingan dengan organisasi tersebut (stakeholders), terutama bagi para penyandang dana (investor atau donatur). Apabila organisasi tersebut bersifat profit oriented maka yang dibutuhkan adalah kepercayaan para investor dan juga kreditur, sedangkan bagi organisasi yang non-profit oriented maka yang dibutuhkan adalah kepercayaan dari para donatur (muzaki). Semakin baik dan professional kinerja suatu organisasi dalam mengelola dana yang telah diamanatkan kepada mereka, maka semakin tinggi kepercayaan para pemilik dana kepada organisasi tersebut sehingga mereka (donatur) lebih termotivasi untuk memberikan atau menanamkan dananya kembali kepada organisasi tersebut. Misalnya ketika kita kaitkan 
dengan pengelolaan ZIS, semakin baik dan professional kinerja OPZ resmi (BAZNAS dan LAZ) dalam melakukan pengelolaan dana ZIS maka kepercayaan para muzaki terhadap OPZ tersebut akan semakin tinggi, yang pada akhirnya mereka akan secara sukarela menyalurkan dana ZISnya kepada OPZ resmi/formal tersebut sehingga optimalisasi ZIS dapat tercapai atau terealisasi.

\section{Akuntansi Zakat dan Infak/Sedekah Berdasarkan PSAK No. 109}

Standar akuntansi ZIS yang berlaku saat ini dan digunakan oleh OPZ sebagai pedoman dalam pembukuan dan pelaporan keuangannya adalah PSAK No. 109 yang dikeluarkan oleh Ikatan Akuntan Indonesia (IAI) pada tahun 2010. Penerbitan PSAK ini telah mengalami proses yang cukup lama kurang lebih empat tahun dari waktu penyusunannya, dimulai dengan disusunnya Eksposure Draft-nya (ED) yang diterbitkan sejak tahun 2008. Namun, saat ini tidak semua OPZ yang ada di Indonesia dapat menerapkan PSAK no. 109. Hal tersebut karena sebagian OPZ mengalami beberapa kendala dalam penerapannya. Salah satu faktor kendalanya adalah adanya kesulitan dalam sumber daya manusia yang dimiliki OPZ.

Akuntansi zakat yang ada dalam Pernyataan Standar Akuntansi Keuangan (PSAK) No. 109 bertujuan untuk mengatur pengakuan, pengukuran, penyajian dan pengungkapan transaksi zakat dan infak/sedekah. PSAK ini berlaku untuk amil yakni suatu organisasi/entitas pengelola zakat yang pembentukannya dan pengukuhannya diatur berdasarkan peraturan perundang-undangan yang dimaksudkan untuk mengumpulkan dan menyalurkan zakat dan infak/sedekah, bukan untuk entitas syariah yang menerima dan menyalurkan ZIS tetapi bukan kegiatan utamanya. Untuk entitas tersebut mengacu ke PSAK 101 mengenai Penyajian Laporan Keuangan Syariah. Amil yang tidak mendapatkan izin juga dapat menerapakan PSAK No. 109. PSAK ini merujuk kepada beberapa fatwa MUI (Washilah dan Nurhayati : 2013) yaitu: 1) Fatwa MUI no. 8/2011 tentang amil zakat, 2) Fatwa MUI No. 13/2011 tentang Hukum Zakat atas Harta Haram, 3) Fatwa MUI No. 14/2011 tantang Penyaluran Harta Zakat dalam bentuk Aset Kelolaan. 4) Fatwa MUI No.15/2011 tentang penarikan, pemeliharaan dan penyaluran harta zakat. 


\section{Pengakuan dan Pengukuran (PSAK 109)}

\section{Akuntansi Untuk Zakat}

a. Penerimaan zakat diakui pada saat kas atau aset nonkas diterima dan diakui sebagai penambah dana zakat. Jika diterima dalam bentuk kas, diakui sebesar jumlah yang diterima tetapi jika dalam bentuk non kas sebesar nilai wajar aset. Penentuan nilai wajar aset nonkas yang diterima menggunakan harga pasar. Jika harga pasar tidak tersedia, maka dapat menggunakan metode penentuan nilai wajar lainnya sesuai dengan PSAK yang relevan.

b. Jika muzakki menentukan mustahik yang harus menerima penyaluran zakat melalui amil, maka aset zakat yang diterima seluruhnya diakui sebagai dana zakat dan tidak ada bagian amil atas zakat yang diterima dan amil dapat menerima ujrah atas kegiatan penyaluran zakat. Jika atas jasa tersebut amil mendapatkan ujrah/fee, maka diakui sebagai penambah dana amil.

c. Penurunan nilai aset zakat diakui sebagai 1. Pengurang dana zakat, jika terjadi tidak disebabkan oleh kelalaian amil; 2. Kerugian dan pengurang dana amil, jika disebabkan oleh kelalaian amil.

d. Zakat yang disalurkan kepada mustahik, diakui sebagai pengurang dana zakat dengan keterangan sesuai dengan kelompok mustahik termasuk jika disalurkan kepada Amil, sebesar: 1. Jumlah yang diserahkan, jika pemberian dilakukan dalam bentuk kas, jurnal, 2. Jumlah tercatat, jika pemberian dilakukan dalam bentuk aset nonkas, jurnal:

e. Amil berhak mengambil bagian dari zakat untuk menutup biaya operasional dalam menjalankan fungsinya.

f. Beban penghimpunan dan penyaluran zakat harus diambil dari porsi amil.

g. Zakat dikatakan telah disalurkan kepada mustahik-non-amil hanya bila telah diterima oleh mustahik-non-amil tersebut. Apabila zakat disalurkan melalui amil lain, maka diakui sebagai piutang penyaluran dan bagi amil yang menerima diakui sebagai liabilitas (utang) penyaluran. Piutang dan liabilitas berkurang ketika zakat disalurkan. Amil lain tidak berhak mengambil bagian dari dana zakat, namun dapat memperoleh ujrah dari amil sebelumnya. 
h. Dana zakat yang disalurkan dalam bentuk perolehan asset tetap (asset kelolaan) diakui sebagai: 1. Penyaluran zakat seluruhnya, jika asset tetap tersebut diserahkan untuk dikelola kepada pihak lain yang tidak dikendalikan amil. 2. Penyaluran secara bertahap diukur sebesar penyusutan asset tetap tersebut sesuai dengan pola pemanfaatannya, jika asset tetap tersebut masih dalam pengendalian amil atau pihak lain yang dikendalikan amil.

i. Amil harus mengungkapkan hal-hal berikut terkait dengan transaksi zakat, tetapi tidak terbatas pada: 1. Kebijakan penyaluran zakat, seperti penentuan skala prioritas penyaluran zakat dan mustahik nonamil; 2. Kebijakan penyaluran zakat untuk amil dan mustahiq nonamil, seperti persentase pembagian, alasan, dan konsistensi kebijakan; 3. Metode penentuan nilai wajar yang digunakan untuk penerimaan zakat berupa asset nonkas.

\section{Akuntansi untuk Infak/Sedekah}

a. Penerimaan Infaq/Sedekah diakui pada saat kas atau aset nonkas diterima dan diakui sebagai penambah dana infaq/sedekah terikat atau tidak terikat sesuai dengan tujuan pemberiannya. Jika diterima dalam bentuk kas, diakui sebesar jumlah yang diterima tetapi jika dalam bentuk nonkas sebesar nilai wajar aset. Untuk penerimaan aset nonkas dapat dikelompokkan menjadi aset lancar dan aset tidak lancar. Aset lancar adalah aset yang harus segera disalurkan, dan dapat berupa bahan habis pakai seperti bahan makan; atau barang yang memiliki manfaat jangka panjang misalnya mobil untuk ambulan. Aset nonkas lancar dinilai sebesar nilai perolehan.

b. Aset tidak lancar yang diterima oleh amil dan diamanahkan untuk dikelola dinilai sebesar nilai wajar saat penerimaannya dan diakui sebagai aset tidak lancar infak/sedekah. Penyusutan dari aset tersebut diperlakukan sebagai pengurang dana infak/sedekah terikat apabila penggunaan atau pengelolaan aset tersebut sudah ditentukan oleh pemberi.

c. Penurunan nilai aset infak/sedekah diakui sebagai: 1. pengurang dana infaq/sedekah, jika terjadi tidak disebabkan oleh kelalaian amil. 2. Kerugian dan pengurang dana amil, jika disebabkan oleh kelalaian amil. 
d. Dana infak/sedekah sebelum disalurkan dapat dikelola dalam jangka waktu sementara untuk mendapatkan hasil yang optimal. Hasil dana pengelolaan diakui sebagai penambah dana infak/sedekah.

e. Penyaluran dana infak/sedekah diakui sebagai pengurang dana infak/ sedekah sebesar:

(a) jumlah yang diserahkan, jika dalam bentuk kas.

(b) nilai tercatat aset yang diserahkan, jika dalam bentuk aset nonkas.

f. Penyaluran infak/sedekah oleh amil kepada amil lain merupakan penyaluran yang mengurangi dana infak/ sedekah sepanjang amil tidak akan menerima kembali aset infak/sedekah yang disalurkan tersebut.

g. Penyaluran infak/sedekah kepada penerima akhir dalam skema dana bergulir dicatat sebagai piutang infak/sedekah bergulir dan tidak mengurangi dana infak/sedekah.

h. Amil harus mengungkapkan hal-hal berikut terkait dengan transaksi infak/sedekah, tetapi tidak terbatas pada:

1) Kebijakan penyaluran infak/sedekah, seperti penentuan skala prioritas penyaluran, dan penerima;

2) Kebijakan pembagian antara dana amil dan dana nonamil atas penerimaan infak/sedekah seperti persentase pembagian, alasan dan konsistensi kebijakan;

3) Metode penentuan nilai wajar yang digunakan untuk penerimaan infak/sedekah berupa asset nonkas;

4) Keberadaan dana infak/sedekah yang tidak langsung disalurkan tetapi dikelola terlebih dahulu, jika ada, maka harus diungkapkan jumlah dan persentase dari seluruh penerimaan infak/sedekah selama periode pelporan serta alasannya.

5) Hasil yang diperoleh dari pengelolaan yang dimaksud di angka (4) diungkapkan secara terpisah

6) Penggunaan dana infak/sedekah menjadi asset kelolaan yang diperuntukkan bagi yang berhak, jika ada, jumlah dan persentase terhadap seluruh penggunaan dana infak/sedekah serta alasannya;

7) Rincian dana infak/sedekah berdasarkan peruntukannya, terikat dan tidak terikat 
8) Hubungan pihak-pihak berelasi antara amil dengan penerima infak/ sedekah yang meliputi: Sifat hubungan istimewa; Jumlah dan jenis asset yang disalurkan; dan Persentase dari asset yang disalurkan tersebut dari total penyaluran selama periode

9) Keberadaan dana nonhalal, jika ada, diungkapkan mengenai kebijakan atas penerimaan dan penyaluran dana, alasan dan jumlahnya;dan

10_Kinerja amil atas penerimaan dan penyaluran dana zakat dan dana infak/ sedekah.

\section{Dana Nonhalal}

a) Penerimaan nonhalal adalah semua penerimaan dari kegiatan yang tidak sesuai dengan prinsip syariah, antara lain penerimaan jasa giro atau bunga yang berasal dari bank konvensional. Penerimaan nonhalal pada umumnya terjadi dalam kondisi darurat atau kondisi yang tidak diinginkan oleh entitas syariah karena secara prinsip dilarang.

b) Penerimaan nonhalal diakui sebagai dana nonhalal, yang terpisah dari dana zakat, dana infak/ sedekah dan dana amil. Aset nonhalal disalurkan sesuai dengan syariah.

\section{Laporan Keuangan Amil Zakat, Infak dan Sedekah}

Laporan keuangan dapat dikatakan sebagai hasil akhir dari suatu proses akuntansi. Tujuan utama dari laporan keuangan adalah menyediakan informasi yang relevan untuk pihak-pihak yang berkepentingan baik pihak internal maupun eksternal misalnya muzakki, pemerintah, piha lain yang menyediakan sumber daya bagi OPZ dan juga masyarakat. Para pihak tersebut memiliki kepentingan yang berbeda-beda dari informasi yang ada dalam suatu laporan keuangan berkaitan dengan pengambilan suatu keputusan. Laporan keuangan juga merupakan bentuk laporan pertanggungjawaban dari manajemen/pengelola atas aktivitas pengelolaan sumberdaya yang telah diamanatkan kepadanya. Secara umum, suatu laporan keuangan menyajikan informasi mengenai (Kurniasari, 2011): 1) Jumlah dan sifat aktiva, kewajiban, dan aktiva bersih suatu organisiasi, 2) Pengaruh transaksi, peristiwa dan situasi lainnya yang mengubah nilai dan sifat aktiva bersih, 3) Jenis dan 
jumlah arus kas masuk dan arus kas keluar sumber daya dalam suatu periode dan hubungan antara keduanya, 4) cara suatu organisasi mendapatkan dan membelanjakan kas, memperoleh pinjaman dan melunasi pinjaman, fan faktor lainnya yang berpengaruh pada likuiditasnya, 5) Usaha jasa suatu organisasi.

Laporan keuangan amil zakat dapat menjadi media komunikasi antara lembaga amil dengan pihak lainnya, karena laporan keuangan ZIS merupakan bentuk pertanggungjawaban operasional dari suatu lembaga amil yaitu kegiatan pengumpulan dan penyaluran dana zakat, infak dan sedekah (ZIS). Supaya laporan keuangan itu transparan dan akuntabel maka harus ada standar akuntansi yang mengatur tentang hal tersebut. Penyusunan laporan keuangan lembaga amil ZIS mengacu kepada PSAK No. 109, dan apabila ada hal-hal yang tidak diatur dalam PSAK 109 maka dapat menggunakan PSAK terait sepanjang tidak bertentangan dengan prinsip syariah Islam. Komponen laporan keuangan dalam PSAK 109 terdiri dari laporan posisi keuangan (Neraca), Laporan Perubahan Dana, Laporan Perubahan Aset Kelolaan, Laporan Arus Kas dan Catatan Atas Laporan Keuangan. Dalam penyajian laporan keuangan, lembaga Amil menyajikan dana zakat, dana infak/sedekah, dana amil dan dana nonhalal secara terpisah dalam neraca (laporan posisi keuangan). Bentuk laporan keuangan untuk amil atau OPZ berdasarkan PSAK No. 109 di antaranya adalah sebagai berikut:

1. Laporan Neraca (laporan posisi keuangan);

Neraca (Laporan Posisi Keuangan)

\section{BAZ "XXX"}

Per 31 Desember $2 X X 2$

\begin{tabular}{|c|c|c|c|}
\hline $\begin{array}{l}\text { Aset } \\
\text { Aset lancar }\end{array}$ & & Kewajiban & \\
\hline Kas dan setara kas & $\mathrm{xxx}$ & Kewajiban jangka pendek & \\
\hline Piutang & $\mathrm{xxx}$ & Biaya yang masih harus dibayar & $\mathrm{Xxx}$ \\
\hline Efek & $\mathrm{xxx}$ & $\begin{array}{l}\text { Kewajiban jangka panjang } \\
\text { Kewajiban Imbalan kerja }\end{array}$ & $\mathrm{xxx}$ \\
\hline $\begin{array}{l}\text { Aset tidak lancar } \\
\text { Aset tetap }\end{array}$ & $\mathrm{XXX}$ & Jumlah kewajiban & $\boldsymbol{X X X}$ \\
\hline Akumulasi penyusutan & $(\mathrm{xxx})$ & & \\
\hline
\end{tabular}




\begin{tabular}{|l|r|l|r|}
\hline Aset & & $\begin{array}{l}\text { Kewajiban } \\
\text { Saldo Dana }\end{array}$ & \\
& & Dana 7akat \\
& & Dana infak/sedekah \\
& & Dana amil \\
& & $\begin{array}{l}\text { Jumlah Saldo dana } \\
\text { Jumlah Kewajiban dan Saldo } \\
\text { Jumlah asset }\end{array}$ & $\mathrm{xxx}$ \\
& $\mathbf{x x x}$ & $\mathrm{xxx}$ \\
\hline
\end{tabular}

2. Laporan Perubahan Dana

\section{Laporan Perubahan Dana}

\section{BAZ "XXX"}

\section{Keterangan \\ DANA ZAKAT}

Penerimaan

Penerimaan dari muzakki

Muzakki entitas

Muzakki individual

Hasil penempatan

Jumlah penerimaan dana zakat

Penyaluran

Fakir-Miskin

Riqab

Gharim

Muallaf

Sabilillah

Ibnu sabil

$\Lambda$ mil

Jumlah penyaluran dana zakat

Surplus (defïsit)

Saldo awal

Saldo akhir

\section{DANA INFAK/SEDEKAII}

\section{Penerimaan}

Infak/sedekah terikat atau muqayyadah

Infak/sedekah tidak terikal alau mullaqah

Hasil pengelolaan

Jumlah penerimaan dana infak/sedekah

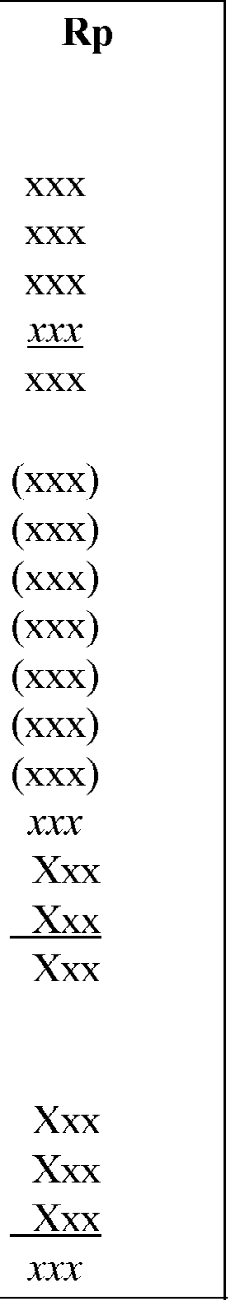




\section{Penerimaan}

Infak/sedekah terikat atau muqayyadah

Infak/sedekah tidak terikat atau mutlacah

I lasil pengelolaan

Jumlah penerimaan dana infak/sedekah

\section{Penyaluran}

Amil

Infak/sedekah terikat atau muqayyadah

Infak/sedekah tidak terikat atau mutlaqah

$\Lambda$ lokasi pemanfaatan aset kelolaan

(misalnya beban penyusutan dan penyisihan)

Jumlah penyaluran dana infak/sedekah

Surplus (defisit)

Saldo awal

Saldo akhir

\section{DANA AMIL}

\section{Penerimaan}

Bagian amil dari dana zakat

Bagian amil dari dana infak/sedekah

Penerimaan lainnya

Jumlah penerimaan

$$
\begin{aligned}
& \mathrm{Xxx} \\
& \mathrm{Xxx} \\
& \mathrm{Xxx} \\
& \hline x x x \\
& \\
& (\mathrm{xxx}) \\
& (\mathrm{xxx}) \\
& (\mathrm{xxx}) \\
& \frac{(x x x)}{\mathrm{xxx}} \\
& \mathrm{xxx} \\
& \mathrm{xxx} \\
& \mathrm{xxx} \\
& \\
& \\
& \mathrm{xxx} \\
& \mathrm{xxx} \\
& \frac{\mathrm{xxx}}{\mathrm{xxx}}
\end{aligned}
$$

3. Laporan Perubahan Aset Kelolaan

Laporan Perubahan Aset Kelolaan

$$
\mathrm{BAZ} \text { "XXX" }
$$

Untuk periode yang berakhir 31 Desember $2 \mathrm{XX} 2$

\begin{tabular}{|l|c|c|c|c|c|c|}
\hline Ketcrangan & $\begin{array}{c}\text { Saldo } \\
\text { Awal }\end{array}$ & Pcnambahan & $\begin{array}{c}\text { Pengura- } \\
\text { ngan }\end{array}$ & $\begin{array}{c}\text { Akumulasi } \\
\text { Penyusutan }\end{array}$ & $\begin{array}{c}\text { Nkumulasi } \\
\text { Penyisihan }\end{array}$ & $\begin{array}{c}\text { Saldo } \\
\text { Akhir }\end{array}$ \\
\hline $\begin{array}{l}\text { Dana infak/ } \\
\text { sedekah-aset } \\
\text { kelolaan lancar } \\
\text { (misal piutang } \\
\text { bergulir) }\end{array}$ & $\mathrm{xxx}$ & $\mathrm{Xxx}$ & $(\mathrm{xxx})$ & - & $(\mathrm{xxx})$ & $\mathrm{xxx}$ \\
\hline $\begin{array}{l}\text { Dana infak/ } \\
\text { sedekah-aset }\end{array}$ & $\mathrm{xxx}$ & $\mathrm{xxx}$ & $(\mathrm{xxx})$ & $(\mathrm{xxx})$ & - & $\mathrm{xxx}$ \\
\hline
\end{tabular}




\begin{tabular}{|l|c|c|c|c|c|c|}
\hline \multicolumn{1}{|c|}{ Ketcrangan } & $\begin{array}{c}\text { Saldo } \\
\text { Awal }\end{array}$ & Penambahan & $\begin{array}{c}\text { Pengura- } \\
\text { ngan }\end{array}$ & $\begin{array}{c}\text { Akumulasi } \\
\text { Penyusutan }\end{array}$ & $\begin{array}{c}\text { Akumulasi } \\
\text { Penyisihan }\end{array}$ & $\begin{array}{c}\text { Saldo } \\
\text { Akhir }\end{array}$ \\
\hline $\begin{array}{l}\text { kelolaan tidak } \\
\text { lancar (misal } \\
\text { rumah sakit } \\
\text { atau sekolah) }\end{array}$ & & & & & & \\
$\begin{array}{l}\text { Dana zakat-aset } \\
\text { kelolaan (misal } \\
\text { rumah sakit atau } \\
\text { sekolah) }\end{array}$ & & & & & & \\
\hline
\end{tabular}

4. Laporan arus kas

Entitas menyajikan laporan arus kas sesuai dengan PSAK 2: Laporan arus kas dan PSAK yang relevan.

5. Catatan atas laporan keuangan

Amil menyajikan catatan atas laporan keuangan sesuai dengan PSAK 101: Penyajian Laporan Keuangan Syariah dan PSAK yang relevan.

\section{Penutup}

Kepercayaan merupakan faktor penting dalam menumbuhkan kesadaran, kepatuhan dan motivasi masyarakat Muslim dalam menunaikan kewajiban ZISnya melalui organisasi resmi atau formal (BAZNAS dan LAZ). Semakin tinggi kepercayaan umat terhadap OPZ maka akan semakin tinggi pula kesadaran, kepatuhan dan motivasi mereka untuk secara sukarela menyalurkan ZISnya ke OPZ formal. Transparansi dan akuntabilitas merupakan faktor penting yang dibutuhkan masyarakat untuk menumbuhkan kepercayaan mereka kepada OPZ. Bentuk transparansi dan akuntabilitas OPZ ditunjukkan dengan laporan keuangan ZIS yang dibuat oleh OPZ disetiap periode dan dipublikasikan melalui berbagai media massa baik media cetak maupun elektronik.

Untuk menghasilkan suatu laporan keuangan ZIS yang baik, maka dibutuhkan penerapan sistem akuntansi yang baik pula. Sistem akuntansi merupakan proses akuntansi yang diawali dari identifikasi transaksi sampai dengan penyusunan laporan keuangan. Dalam pelaksanaan proses akuntansi dibutuhkan standar/pedoman akuntansi yang mengatur tentang pengakuan, 
pengukuran, penyajian dan pengungkapan transaksi zakat dan infak/sedekah. Standar akuntansi ZIS yang berlaku di Indonesia yaitu PSAK No. 109 tentang akuntansi ZIS yang dikeluarkan oleh Ikatan Akuntan Indonesia (IAI) dan disyahkan pada tahun 2010. PSAK ini berlaku untuk amil yakni suatu organisasi/entitas pengelola zakat yang pembentukannya dan pengukuhannya diatur berdasarkan peraturan perundang-undangan yang dimaksudkan untuk mengumpulkan dan menyalurkan zakat dan infak/sedekah, bukan untuk entitas syariah yang menerima dan menyalurkan ZIS tetapi bukan kegiatan utamanya. Dengan PSAK 109 tersebut diharapkan dapat tercipta keseragaman (uniformity) dan keterbandingan (comparability) laporan keuangan yang dibuat dan supaya OPZ juga siap untuk diaudit oleh akuntan publik. Saat ini sebagian OPZ dalam membuat laporan keuangan masih belum menerapkan PSAK 109, sebagian OPZ masih menggunakan pelaporan keuangan yang sederhana sehingga bentuk dan format pelaporan tiap OPZ menjadi berbeda-beda. Faktor penyebab belum diterapkannya PSAK 109 di sebagian OPZ adalah kesulitan dalam menerapkannya karena kendala sumber daya manusia yang dimiliki OPZ. Sehingga untuk mengatasi permasalahan tersebut diperlukan pelatihan dan pendampingan bagi OPZ terkait penerapan PSAK 109.

\section{Daftar Pustaka}

Anshori, Ghofur Abdul, 2006, Hukum dan Pemberdayaan Zakat, Cetakan Pertama, Pilar Media, Yogyakarta.

Al-Qardhawi, Yusuf,1991, Fiqh al-Zakah,Muassasah Risalah, Beirut Hafidhudin, Didin, 2002, Zakat dalam Perekonomian Modern, Cetakan Ketujuh, Gema Insani, Jakarta

Hariningsih.2006. Sistem Informasi Akuntansi. Edisi Pertama. Yogyakarta: Ardana Media

Ikatan Akuntan Indonesia. 2011. Pernyataan Standar Akuntansi Keuangan Nomor 109. Jakarta: IAI

Ikatan Akuntan Indonesia. 2007. Pernyataan Standar Akuntansi Keuangan Nomor 45. Jakarta:IAI

Jusup, Haryono Al. 2005. Dasar-Dasar Akuntansi. Edisi Keenam. Yogyakarta: STIE YKPN 
Kurniasari, Wiwin. Transparansi Pengelolaan Masjid dengan Laporan Keuangan Berdasarkan Pernyataan Standar Akuntansi Keuangan (PSAK 45).Jurnal Muqtashid. Vol.2, No.1 Juni 2011: STAIN Salatiga

Mulyadi. 1993. Akuntansi Manajemen: Konsep, Manfaat dan Rekayasa. Edisi Kedua. Yogyakarta: STIE YKPN

Mulyadi. 2001. Sistem Akuntansi. Cetakan Ketiga. Jakarta: Salemba Empat

Nurhayati, Sri dan Wasilah. 2013. Akuntansi Syariah di Indonesia. Jakarta: Salemba Empat

PIRAC. 2007. Meningkat, Kesadaran dan Kapasitas Masyarakat dalam Berzakat. (Online), (http:// pirac.org/wp-content/uploads/2012/.../ Press-Release-Seminar-Zakat.pdf).

Undang-Undang Republik Indonesia Nomor 23 Tahun 2011 Tentang Pengelolaan Zakat

Wilson, Earl R and Kattelus, Susan C. 2004. Accounting for Govermental and Nonprofit Entities. 13 ${ }^{\text {th }}$ Edition. New York: McGraw-Hill.

http://ahmadjuwaini.com/2013/11/setelah-judicial-review-uu-zakat: Setelah Judicial Review UU Zakat, diakses 20 Desember 2013.

www. antaranews.com/berita/371882/potensi-zakat-indonesia-baru-terserapsatu-persen senin, 29 april 2013, diakses 15 Desember 2013

Majalah Zakat Edisi Mei 2013, BAZNAS, www.pusat.baznas.go.id 